Article

\title{
Impact of the Type of Fertilization and the Addition of Glycerol on the Quality of Spring Rape Straw Pellets
}

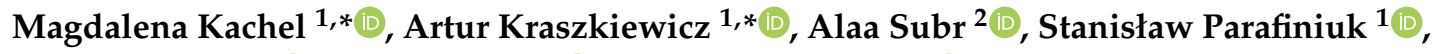 \\ Artur Przywara ${ }^{1}$, Milan Koszel ${ }^{1}\left(\mathbb{D}\right.$ and Grzegorz Zając ${ }^{3} \mathbb{D}$ \\ 1 Department of Machinery Exploitation and Management of Production Processes, Faculty of Production \\ Engineering, University of Life Sciences in Lublin, Głęboka 28, 20-612 Lublin, Poland; \\ stanislaw.parafiniuk@up.lublin.pl (S.P.); artur.przywara@up.lublin.pl (A.P.); \\ milan.koszel@up.lublin.pl (M.K.) \\ 2 Department of Agricultural Machines and Equipment, College of Agricultural Engineering Sciences, \\ University of Baghdad, Baghdad, Al-Jadiriya 10071, Iraq; alaa.kamel@coagri.uobaghdad.edu.iq \\ 3 Department of Power Engineering and Transportation, University of Life Sciences in Lublin, Głęboka 28, \\ 20-612 Lublin, Poland; grzegorz.zajac@up.lublin.pl \\ * Correspondence: magdalena.kachel@up.lublin.pl (M.K.); artur.kraszkiewicz@up.lublin.pl (A.K.)
}

Received: 15 January 2020; Accepted: 11 February 2020; Published: 13 February 2020

\begin{abstract}
This paper presents an analysis of selected qualitative characteristics of pellets produced from rape straw obtained from cultivations subjected to different fertilization treatments and from mixtures of straw selected for testing with crude glycerol obtained as a by-product from biodiesel production. The assessment focused on the following qualities of the obtained pellets: Moisture content, mechanical durability, heating value and main elements, that is, carbon, hydrogen, nitrogen, sulphur, chlorine and oxygen. The obtained results indicated that the different treatment regimens applied in spring rape cultivations had a significant impact on the physicochemical qualities of the straw. In terms of the heating value, traditional fertilization with multi-component fertilizer (NPK) yielded slightly lower chemical parameters (lower carbon content and heat of combustion) than in the case of straw obtained from the control sample and from the plot fertilized with digestate. Furthermore, in all of the analysed mixtures, the $10 \%$ addition of raw glycerol improved the mechanical characteristics of the produced straw pellets. After the $10 \%$ glycerol addition, in terms of the energetic use of these biofuels, the parameters of the fuel, such as heating value and net heating value, were slightly decreased.
\end{abstract}

Keywords: agricultural biomass; biofuel; mechanical durability; physicochemical properties

\section{Introduction}

One of the primary premises of sustainable agriculture is the development of efficient and environmentally friendly technologies to be used both in the production of crops and in the processes of utilising agricultural by-products, with the aim of protecting soil quality and preventing further degradation of the natural environment [1]. One of the approaches consistent with the philosophy of sustainable development entails the use of biofertilizers in the form of digestate from biogas plants. The policies adopted in particular countries with regard to utilizing this type of by-product, particularly in terms of its specific definition and chemical composition, provide the basis for the development of practical procedures. In general, the idea is to optimise the content of nutrients that the digestate-based fertilizer will provide to the plants and soil. This approach helps to minimise the negative impact of cultivation on the natural environment, maximise the revenue for farmers who are able to generate better yields, improve the quality of grain and grain products and facilitate a more effective use of the by-products (straw, glycerol), for example, in pellet production. 
The growing global energy demand has led to an increased reliance on fossil fuel and, consequently, greater $\mathrm{CO}_{2}$ emissions, which over the last three decades have been increasing by $1.9 \%$ annually [2]. The environmental impact of energy production, particularly in terms of $\mathrm{CO}_{2}$ emissions, can be reduced by resorting to renewable, low-emission energy sources [3,4], which have the added benefit of limiting the emissions of other harmful compounds such as $\mathrm{NO}_{x}$ and $\mathrm{SO}_{2}$ [5]. It is currently generally assumed that biomass fuels are characterised by worse physicochemical properties than fossil fuels, particularly in terms of bulk density and net heating value, which hinders their potential as a more generally applicable energy source [6]. Furthermore, the chemical composition of straw can vary significantly depending on the plant species, growth conditions (fertilization), region of harvest and inherent moisture content [7,8]. As observed by Karcz et al. [9], compared to cereal straw, rape straw is characterised by a higher content of carbon, nitrogen, sulphur and chlorine. Preliminary processing of the material through, for example, torrefaction and pelletization, allows many of the material's drawbacks to be rectified [10,11]. Improving such qualities contributes to a higher comfort of use, which can be comparable to gas-based heating systems [12], while other benefits of pelletized fuel can increase its marketability $[13,14]$.

The quality of the raw material is the critical factor influencing the process of production and the quality of the end product [15]. However, efforts aimed at determining the optimum raw material mixtures and additives to sufficiently improve the quality of the produce continue to pose a considerable challenge for the power industry [12-15]. One of the most commonly used additives which influences the quality of the final pellet is crude glycerol, obtained as a by-product in the production of liquid biofuel, fatty acid methyl esters (FAME) or rapeseed oil methyl ester (RME), from vegetable oil $[11,16,17]$. Given the currently intensifying production of such biofuels, finding a suitable way to utilize crude glycerol is becoming an important issue [18-20]. The reuse of glycerol is necessary both for economic and ecological reasons [21]. The chemical composition and parameters of raw glycerol depend primarily on the type of catalyst used in biofuel production, the efficiency of the production process itself and the presence of impurities in the raw material [22]. Studies show that in the case of edible plants, ligno-cellulosic biomass, microalgae, animal/vegetable oil and so forth—which are commonly used for biodiesel production by way of transesterification-glycerol, as a by-product, amounts to $10 \%$ of the total biodiesel produce $[23,24]$. The European Union (EU) remains the world's largest biodiesel producer with a production capacity of 24.9 billion litres reported in 2016; this was expected to increase to 25.5 billion litres by 2017 [25]. For every tonne of oil processed, approximately $100 \mathrm{~kg}$ of glycerol remain [26].

During thermal biomass processing, undesirable processes are often observed inside the boilers-Sediments and sintered product deposits are formed on the heat-exchange surfaces. One of the main factors responsible for these problems is the biomass content of minerals [7], whose chemical behaviour during biomass combustion is dictated by the presence of metals, chlorine and sulphur. The process of deposition in the presence of sulphates and especially chlorine compounds significantly increases the rate of high-temperature corrosion. For this reason, it is necessary to monitor the content of this elements in fuels intended for energy production [27].

The aim of the presented study was to analyse selected qualitative traits of pellets produced from rape straw obtained from cultivations subjected to different fertilization treatments, as well as from mixtures of such straw with crude glycerol obtained as a by-product of biodiesel production.

\section{Methods}

\subsection{Origin of the Material}

The research material consisted of randomly selected $25 \mathrm{~kg}$ samples of rape straw obtained from spring rape cultivations subjected to two types of fertilization treatment.

In the first variant, before sowing, the soil was treated with digestate obtained from the agricultural biogas plant located in the town of Piaski, Lubelskie Voivodeship, Poland (electric power 0.99 MW, 
thermal power 1.1 MW, annual electricity production approximately $8400 \mathrm{MWh}$ ). The feedstock for the biogas plant consisted of green waste in the form of maize silage and whey. Before use, the digestate was analysed in terms of microelement and heavy metal content (Table 1), as well as $\mathrm{pH}$ value, which in this case was 8.73. The study was conducted at the Regional Agrochemical Station in Lublin.

Table 1. Total contents of macronutrients and selected heavy metals in digestate used for cultivating spring rape.

\begin{tabular}{cc}
\hline Element & Content \\
\hline $\mathrm{N}\left[\mathrm{g} \cdot \mathrm{dm}^{-1}\right]$ & $0.119^{*}$ \\
$\mathrm{P}\left[\mathrm{g} \cdot \mathrm{dm}^{-1}\right]$ & $0.12^{* *}$ \\
$\mathrm{~K}\left[\mathrm{~g} \cdot \mathrm{dm}^{-1}\right]$ & $5.37^{* *}$ \\
$\mathrm{Ca}\left[\mathrm{g} \cdot \mathrm{dm}^{-1}\right]$ & $0.28^{* *}$ \\
$\mathrm{Mg}\left[\mathrm{g} \cdot \mathrm{dm}^{-1}\right]$ & $0.07 * *$ \\
$\mathrm{Cd}\left[\mathrm{mg} \cdot \mathrm{dm}^{-1}\right]$ & $<0.43$ \\
$\mathrm{~Pb}\left[\mathrm{mg} \cdot \mathrm{dm}^{-1}\right]$ & $<0.43$ \\
$\mathrm{Ni}\left[\mathrm{mg} \cdot \mathrm{dm}^{-1}\right]$ & $<0.43$ \\
$\mathrm{Cr}\left[\mathrm{mg} \cdot \mathrm{dm}^{-1}\right]$ & $<0.43$ \\
$\mathrm{Mg}\left[\mathrm{mg} \cdot \mathrm{dm}^{-1}\right]$ & 0.43 \\
$\mathrm{Zn}\left[\mathrm{mg} \cdot \mathrm{dm}^{-1}\right]$ & 2.00 \\
$\mathrm{Mn}\left[\mathrm{mg} \cdot \mathrm{dm}^{-1}\right]$ & 2.26 \\
$\mathrm{Fe}\left[\mathrm{mg} \cdot \mathrm{dm}^{-1}\right]$ & 70.82 \\
\hline
\end{tabular}

* Analyzed according to CLA/PSO/13/2013 standard; ** Analyzed according to KQ/PB-76; other elements analyzed according to $\mathrm{KQ} / \mathrm{PB}-17$ standard.

The second variant entailed the use of commercially available multi-component fertilizer-Yara NPK 5-14-28 (5\% N ammonia nitrogen, 14\% P, 28\% K, 12.5\% $\mathrm{SO}_{3}$ and 3\% CaO) at a rate of $0.405 \mathrm{~kg} / \mathrm{plot}$ $\left(150 \mathrm{~kg} \cdot \mathrm{ha}^{-1}\right)$. The dosage of each of the fertilizers was determined in accordance with the manufacturers' recommendations. Each experiment was conducted in triplicate, as control measurements were also carried out on material grown without the use of digestate or multi-component fertilizer (NPK).

\subsection{Research Material}

The research material in the form of crude glycerol was obtained in a $3 \mathrm{~L}$ container. The raw material originated from a batch of rapeseed oil biofuel produced in Trzebinia S.A. Refinery, voivodeship Małopolskie Poland, in 2017. The elemental analysis in terms of the main components' content was conducted in accordance with the applicable standards-For glycerine, sulphate ash and water, methanol-EN ISO 14110:2004 [28]; for matter organic non glycerol (MONG)—MONG-WT 93/2009 [29]; and for C, H, N, S and chloride-Eur.Ph.2005:496 [30].

The content of carbon, hydrogen and nitrogen in crude glycerol was determined with the use of a CHN 628 elemental analyser by LECO. The content of carbon, hydrogen and nitrogen in glycerine was determined with the use of instrumental methods ( $\mathrm{C}$ and $\mathrm{H}$ through high-temperature incineration with IR detection and $\mathrm{N}$ with the use of the catharometric method), in accordance with EN ISO 15104 [31], EN ISO 16948:2015-07 [32] and $0.1 \mathrm{~g}$ was weighed in accordance with the requirements.

Rape straw was shredded using an H 111 hammer mill with $8 \mathrm{~mm}$ sieves. Moisture and bulk density of comminuted raw materials were determined according to EN ISO 14774-3:2010 [33] and EN ISO 17828:2016 [34], respectively. After being shredded, the straw bulk density was $78 \pm 2 \mathrm{~kg} \cdot \mathrm{m}^{-3}$. Then, the straw was divided into two batches. The first batch was left untreated while the second batch was mixed with $10 \%$ crude glycerol by stirring for $20 \mathrm{~min}$ to ensure an even distribution of the additive. Both batches of straw were also moistened with water to obtain moisture of the material before compacting about $16 \%$. The thus-prepared raw material was left for $24 \mathrm{~h}$ in jute bags at a temperature of $20^{\circ} \mathrm{C}$. Next, the material was condensed using a granulator with a fixed, flat, one-sided matrix of $25 \mathrm{~mm}$ in thickness and hole diameter of $8 \mathrm{~mm}$. The rotational speed of the pressing rollers 
was $110 \mathrm{rpm}$ and the rollers were powered by a $7.5 \mathrm{~kW}$ electric motor via a gear assembly. Examples of the pellets obtained are shown in Figure 1.

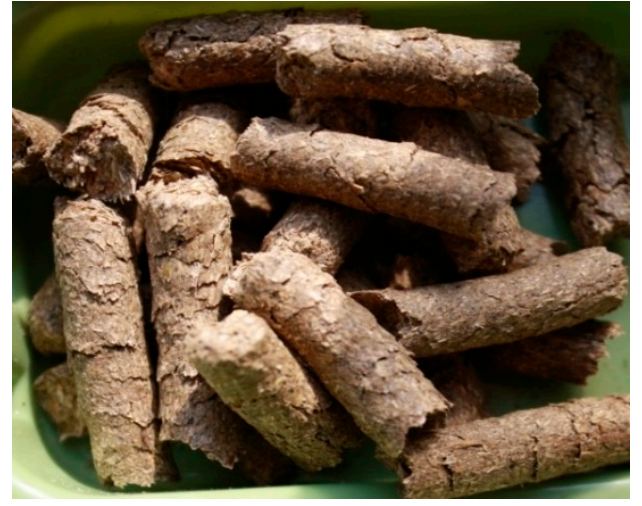

(a)

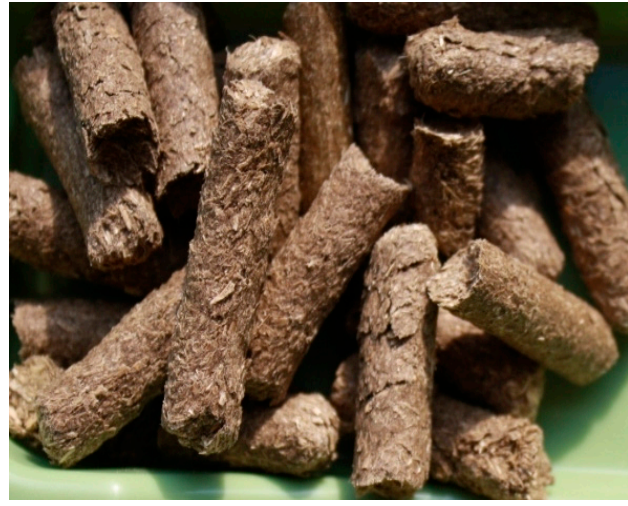

(b)

Figure 1. Pellets made of rape straw-(a) Multi-component fertilizer (NPK) fertilization; (b) NPK fertilization + glycerol 10\%.

\subsection{Physicochemical Properties of Pellets}

The moisture content (MC) of pellets was determined using a laboratory oven with forced air circulation. Samples of raw materials or pellets were placed in the oven and dried at $105{ }^{\circ} \mathrm{C}$ until a constant mass was reached, in accordance with EN ISO 14774-3:2010 [33].

The measurements of pellet mechanical durability (MD) were carried out on a test bench in accordance with EN ISO 17831-1:2015 [35]. The rotational speed of the drum was $50 \mathrm{rpm} \cdot \mathrm{min}^{-1}$ $\left( \pm 0.1 \mathrm{rpm} \cdot \mathrm{min}^{-1}\right)$, the duration of the measurement was $10 \mathrm{~min}$ and the mass of the sample was $500 \mathrm{~g}( \pm 10 \mathrm{~g})$. After the mechanical durability test, the tested sample was sieved using a sieve with $3.15 \mathrm{~mm}$ holes.

The content of carbon $(\mathrm{C})$, hydrogen $(\mathrm{H})$, nitrogen $(\mathrm{N})$, total sulphur $(\mathrm{S})$ and chlorine $(\mathrm{Cl})$ was measured at the Energy Research and Measurement Laboratory "Energopomiar Spółka z o.o." in Gliwice, Poland. For carbon and hydrogen, the measurements were carried out in accordance with EN ISO 16948:2015-07 [32] using an automatic IR analyser; for nitrogen measurements were made using the catharometric method in accordance with EN ISO 16948:2015-07 [32]; for sulphur measurements were made with the use of an automatic IR analyser in accordance with EN ISO 16994:2015-06 [36]; and for chlorine measurements were made by way of ion chromatography in accordance with EN ISO 16994:2015-06 [36].

The analysis of sample density was carried out with a DM-340 series Den-Di portable laboratory densitometer (LEMIS INSTRUMENTS AS LEMIS Baltic, Riga, Latvia) used in petrochemical, chemical and pharmaceutical industries.

The higher heating value (HHV) was determined using a Parr 6400 automatic isoperibolic calorimeter (by Parr Instrument Company, USA) in accordance with EN ISO 14918:2009 [37]. The measurement consisted in complete combustion of a 1-2 g $( \pm 0.0001 \mathrm{~g})$ sample of the analysed product in an oxygen atmosphere under a pressure of $3 \mathrm{MPa}$ in a bomb calorimeter immersed in water.

The lower heating value (LHV) of the produced pellets was calculated on the basis of the heat of combustion measured by calorimetric method using isoperibolic calorimeter, in accordance with EN ISO 14918:2009 [37].

The ash content $(\mathrm{AC})$ was measured after ashing the pellet sample at a final temperature of $550{ }^{\circ} \mathrm{C}$, in accordance with EN ISO 14775:2009 [38].

Each measurement was conducted in three repetitions. 


\subsection{Statistical Analysis}

The results obtained for the selected oil products were analysed statistically by determining the mean value \pm standard deviation, as well as by employing the post-hoc Tukey's test, with the significance level set at $p<0.05$, using Statistica 10 software from StatSoft, Cracow, Poland.

\section{Results and Discussion}

The results of digestate elemental analysis are presented in Table 1.

The analysis revealed that the digestate used in the field experiment contained less nitrogen, phosphorus and potassium than the traditional NPK fertilizer used in the other variant. The obtained values were $0.119,0.12$ and $5.37 \mathrm{~g} \cdot \mathrm{dm}^{-1}$ for nitrogen, phosphorous and potassium, respectively (Table 1 ). The content of heavy metals was within the acceptable range, which confirms the usability of the digestate as a crop fertilizer $[39,40]$. It is also important to note that the elemental analysis of the digestate was comparable to results reported by other authors [41].

Monitoring the content of such elements is important, as using mixtures containing heavy metals in the production of plant material will ultimately contribute to increasing the content of the same elements in the soil ( $\mathrm{Cr}, \mathrm{Hg}, \mathrm{Pb}, \mathrm{Zn}$, etc.) [42]. However, when properly applied and introduced into the soil, this type of fertilizer may prove beneficial to agricultural production as well as the natural environment [43]. At the same time, certain characteristics of digestate (smell, high moisture content and considerable content of solids) [44] may discourage its direct agricultural application. It is currently commonly accepted in this context that further data are required with regard to the actual physicochemical properties and biodegradability of digestate [45].

Table 2 presents the basic physicochemical properties of crude glycerol used in the experiment.

Table 2. Physicochemical properties of by-products from the production of the analysed biofuels.

\begin{tabular}{ccc}
\hline Parameter & Unit & Technical Glycerine \\
\hline Higher heating value & $\mathrm{MJ} \cdot \mathrm{kg}^{-1}$ & $16.051 \pm 0.03$ \\
Density & $\mathrm{kg} \cdot \mathrm{m}^{-3}$ & $1283 \pm 1.52$ \\
Glycerine content & $\%$ & $91.02 \pm 0.03$ \\
Water content & $\%$ & $3.65 \pm 0.06$ \\
Sulphated ash content & $\%$ & $3.54 \pm 0.04$ \\
Methanol content & $\%$ & $0.15 \pm 0.05$ \\
MONG content & $\%$ & $1.64 \pm 0.06$ \\
$\mathrm{C}$ & $\%$ & $36.76 \pm 0.08$ \\
$\mathrm{H}$ & $\%$ & $8.33 \pm 0.12$ \\
$\mathrm{~N}$ & $\%$ & $0.80 \pm 0.05$ \\
$\mathrm{~S}$ & $\%$ & $0.38 \pm 0.01$ \\
$\mathrm{Cl}$ & $\mathrm{ppm}$ & $<9 \pm 0.04$ \\
\hline
\end{tabular}

Glycerol higher heat of combustion was $16,051 \mathrm{MJ} \cdot \mathrm{kg}^{-1}$. According to numerous publications, glycerol is characterised by a limited heating value, roughly within the range of 16.07 to $19.2 \mathrm{MJ} \cdot \mathrm{kg}^{-1}$, which is insufficient for it to be considered a suitable fuel material [46,47]. In practical terms, the primary factor considered in the assessment of raw materials in terms of their energy producing potential is their net heating value which largely depends on the fuel's total moisture content. When the total moisture content increases, the net heating value of the fuel is decreased [48]. In the case of crude glycerol, the level of water contamination can significantly affect its heating characteristics [49].

Selected physical and heating properties of the pellets are presented in Table 3. 
Table 3. Physical and heating properties of the pellets.

\begin{tabular}{|c|c|c|c|c|c|c|}
\hline \multirow{2}{*}{ Object } & $\mathrm{MC}^{\mathrm{r}}$ & $\mathrm{MC}^{\mathrm{a}}$ & $\mathrm{MD}^{\mathrm{a}}$ & $\mathrm{HHV}^{\mathrm{d}}$ & LHV $^{d}$ & $A C^{a}$ \\
\hline & $\%$ & $\%$ & $\%$ & $\mathrm{MJ} \cdot \mathrm{kg}^{-1}$ & $\mathrm{MJ} \cdot \mathrm{kg}^{-1}$ & $\%$ \\
\hline Control & $10.21 \pm 0.05 a, b^{* *}$ & $2.31 \pm 0.05 a, b^{* *}$ & $89.08 \pm 0.02$ & $18.45 \pm 0.02 a, b * *$ & $17.27 \pm 0.02 a, b^{* *}$ & $9.59 \pm 0.99$ \\
\hline Digestate & $11.25 \pm 0.15 d^{* *}$ & $3.25 \pm 0.20 \mathrm{~d}^{* *}$ & $90.23 \pm 0.02$ & $\begin{array}{c}18.25 \pm \\
0.13 \mathrm{~b}, \mathrm{c}, \mathrm{d}, \mathrm{e}, \mathrm{f} * *\end{array}$ & $17.03 \pm 0.16 \mathrm{~b}, \mathrm{c}, \mathrm{d}^{* *}$ & $9.27 \pm 0.41$ \\
\hline Control + glycerol 10\% & $10.31 \pm 0.62 \mathrm{a}, \mathrm{c}$ ** & $2.41 \pm 0.92 \mathrm{a}, \mathrm{c} * *$ & $94.99 \pm 0.02$ & $18.29 \pm 0.5 \mathrm{a}, \mathrm{c} * *$ & $17.03 \pm 0.17 \mathrm{a}, \mathrm{c} * *$ & $8.93 \pm 0.15$ \\
\hline
\end{tabular}

Abbreviations: NPK-multi-component fertilizer, $\mathrm{MC}^{\mathrm{r}}$-Moisture Content in working condition, $\mathrm{MC}^{\mathrm{a}}$-Moisture Content in analytical state, $\mathrm{MD}^{\mathrm{a}}-$ Mechanical Durability in analytical state, $\mathrm{HHV}^{\mathrm{d}}$ - Higher Heating Value in dry matter, $\mathrm{LHV}^{\mathrm{d}}$-Lower Heating Value in dry matter, $A C^{\mathrm{a}}$-Ash Content in analytical state; ${ }^{* *} \mathrm{a}, \mathrm{b}, \mathrm{c} \ldots$ - . -values marked with the same letters do not differ significantly at the level $\alpha=0.05$.

The mean moisture content in the analysed pellets (Table 3) produced without additives and with the addition of crude glycerol was within the range from $10.19 \%$ to $12.15 \%$. The lowest value of this parameter was observed for pellets produced from straw obtained from the digestate-fertilized cultivation in a mixture with glycerol $(10.19 \%)$, while the highest value was recorded for the pellet sample from the traditional cultivation treated with NPK, without the addition of glycerol. The glycerol used in this particular experiment was characterised by a relatively low water content, which may have been a factor affecting the lower water content in the samples containing the additive. In a study conducted by Bartocci et al. [21], the addition of glycerol led to an increase in the content of water and volatile compounds in the pellets.

In a study by Emamil et al. [50], the lowest density was observed for pellets containing $7.5 \%$ glycerol. This may be due to the fact that glycerol induces the formation of a barrier to straw particle binding in the process of pelletization. No significant impact of the tested levels of glycerol content on durability was observed [50].

The mechanical durability of the analysed agglomerate, which impacts the pellets' susceptibility to damage during transport and storage, is presented in Table 3. Under the tested conditions, the mean mechanical durability of the pellets was within the range from $89.08 \%$ in the control sample to $93.78 \%$ in the sample of rape straw pellets from plants treated with the traditional fertilizer. On average, the addition of glycerol resulted in an approx. 3\% increase of this parameter; for NPK with glycerol 10\%, this brought it within range class $B$ of the guidelines provided by the qualitative standards applicable to this type of agglomerate [51,52].

The higher heat of combustion measurements for pellets from the analysed experimental variants returned no values lower than $18 \mathrm{MJ} \cdot \mathrm{kg}^{-1}$, while the lower heating value of the pellets of the respective experimental variants did not exceed $17.27 \mathrm{MJ} \cdot \mathrm{kg}^{-1}$ (pellets from rape straw harvested from the control sample field). The addition of crude glycerol resulted in a slight decrease of the above parameters (Table 3). A statistical analysis with the use of Tukey's test revealed borderline significance of the differences between the heating value of pellets produced from straw of plants treated with traditional NPK fertilizers on the one hand and all the remaining pellet variants on the other.

Ash content has a negative impact on the heating value of fuel and the processes of its combustion. It is dependent on the particular type of biomass and is usually between $0.3 \%$ and $10 \%$ in woody biomass and between $1.3 \%$ and $16.3 \%$ of ash in agricultural biomass [48,53].

Most agricultural biomass is characterised by a high ash content related to the type of raw material used, low ash softening point and high risk of corrosion and furnace contamination. During biomass combustion, organic compounds are gasified and inorganic elements remain in the form of salts, for example, $\mathrm{CaO}, \mathrm{K}_{2} \mathrm{CO}_{3}$ or $\mathrm{MgO}$, which produce ash. In a study by Emamil et al. [50], the lowest ash content was reported for samples containing $7.5 \%$ of glycerol, while the highest in pellets obtained from barley and wheat straw included in the control sample $(0.0 \%$ glycerol).

In the present study, the highest ash content was recorded for the control sample without the addition of glycerol (9.59\%) and pellets produced from 100\% rape straw from plants fertilized with 
digestate $(9.23 \%)$. The lowest ash content was observed in straw pellets from traditionally fertilized plants $(8.88 \%)$. The addition of crude glycerol resulted in an approximate $7 \%$ decrease of ash content in the analysed mixtures (Table 3). A statistical analysis comparing the analysed pellet types at the significance level of $p=0.93$ did not reveal significant differences in terms of the ash content.

The elemental composition of the studied biofuels is presented in Table 4.

Table 4. Elemental dry mass composition of pellets.

\begin{tabular}{cccccc}
\hline \multirow{2}{*}{ Object } & $\mathbf{C}$ & $\mathbf{H}$ & $\mathbf{N}$ & $\mathbf{S}$ & $\mathbf{C l}$ \\
\cline { 2 - 6 } & \multicolumn{5}{c}{$\%$} \\
\hline Control & $47.42 \pm 0.03$ & $5.38 \pm 0.04 \mathrm{a}, \mathrm{b}^{* *}$ & $1.15 \pm 0.02$ & $0.78 \pm 0.02$ & $0.84 \pm 0.03$ \\
NPK & $47.15 \pm 0.02$ & $5.40 \pm 0.03 \mathrm{a}, \mathrm{e}^{* *}$ & $1.23 \pm 0.01$ & $0.74 \pm 0.03 \mathrm{a} * *$ & $0.69 \pm 0.02$ \\
Digestate & $47.54 \pm 0.02$ & $5.40 \pm 0.01 \mathrm{~b}, \mathrm{e}^{* *}$ & $1.07 \pm 0.02$ & $0.73 \pm 0.02$ & $0.86 \pm 0.01$ \\
Control + gl.10\% & $46.33 \pm 0.03$ & $5.67 \pm 0.02 \mathrm{c}, \mathrm{d}^{* *}$ & $1.11 \pm 0.03$ & $0.75 \pm 0.02 \mathrm{a} * *$ & $0.75 \pm 0.02$ \\
NPK + gl.10\% & $46.11 \pm 0.03$ & $5.71 \pm 0.02 \mathrm{c}, \mathrm{f}^{* *}$ & $1.18 \pm 0.02$ & $0.70 \pm 0.01$ & $0.62 \pm 0.03$ \\
Digestate + gl.10\% & $46.47 \pm 0.04$ & $5.69 \pm 0.01 \mathrm{~d}, \mathrm{f}^{* *}$ & $1.05 \pm 0.01$ & $0.69 \pm 0.02$ & $0.77 \pm 0.02$ \\
\hline
\end{tabular}

** a,b,c ...-values marked with the same letters do not differ significantly at the level $\alpha=0.05$.

The highest content of $\mathrm{C}$ was recorded in pellets produced from straw obtained from the digestate-treated cultivation and the control sample. The lowest value of $C$ was observed for pellets from straw obtained from the cultivation fertilized with traditional NPK. The addition of $10 \%$ glycerol reduced the pellets' carbon content by slightly over $2 \%$. The content of hydrogen was fairly uniform between the analysed samples and remained at the level of approximately $5.4 \%$, while in the mixtures containing glycerol it increased to approximately $5.7 \%$ (Table 4). The carbon content in plant biomass is usually within the range of 40-55\% [54,55]. Obernberger et al. [15] reported that the carbon content in woody biofuels (including bark) is higher than in the case of green biofuels, which results in a slightly higher heat of combustion for dendromass. The content of hydrogen is less changeable and oscillates around $6 \%$. A higher content of carbon and hydrogen is beneficial to the given fuel's energy use potential, while higher nitrogen content contributes to the reduction of the same [54]. The performed statistical analysis did not reveal the presence of homogenous groups in terms of the carbon content in the respective samples, whereas with regard to the hydrogen content, the following homogenous groups were identified-NPK and Control, digestate and Control, NPK $10 \%$ and Control 10\%, digestate $10 \%$ and Control $10 \%$.

The content of nitrogen and sulphur in biomass is significantly lower, within the range of several percent [53]. The content of nitrogen recorded in all the experimental variants was within the range from $1.07 \%$ (digestate fertilization) to $1.23 \%$ (NPK fertilization). The addition of glycerol reduced this parameter to more desirable levels. As observed by Obernberger et al. [15], during combustion the nitrogen contained in fuel is almost entirely converted into its gaseous form of $\mathrm{N}_{2}$ and nitrogen oxides $\left[\mathrm{NO}_{\mathrm{x}}\left(\mathrm{NO}, \mathrm{NO}_{2}\right)\right]$. The amount of dinitrogen monoxide $\left(\mathrm{N}_{2} \mathrm{O}\right)$ is very low, particularly in modern heating appliances using solid biofuels. Only a very small amount of nitrogen is contained in ash. The $\mathrm{NO}_{\mathrm{x}}$ emission increases with the growing content of nitrogen in the fuel, which must be considered when using biomass fuels containing nitrogen $[29,53]$. The problem of increased $\mathrm{NO}_{\mathrm{x}}$ emissions occurs once the weight content of nitrogen reaches or exceeds $0.6 \%$. This is particularly pertinent with respect to cereal straw, grasses and fruit residues [56]. In studies by Topolnicka et al. [49] and Kucinskas et al. [56], a slight increase in $\mathrm{NO}_{\mathrm{x}}$ emission was observed after the introduction of crude glycerol into the fuel mixture.

The content of sulphur in the analysed pellets without the addition of glycerol was within the range of $0.73 \%$ to $0.78 \%$ and with the additive from $0.69 \%$ to $0.75 \%$. Some crops have a tendency to accumulate sulphur (e.g., rape). The content of sulphur in plant biomass tends to fluctuate between $0.03 \%$ and $0.5 \%$ and rarely exceeds this value [17]. Notably, the highest sulphur content is typically observed in rape, olive pomace and straw [57]. Numerous studies pertaining to the content of sulphur 
(S) in solid biofuels have been conducted and the reported content of the element was between $0.16 \%$ and $21.00 \%$ [58-61]. The conducted statistical analysis did not reveal the presence of homogenous groups with respect to the nitrogen content in the analysed pellet samples, while in terms of the sulphur content, one uniform group was identified between NPK and Control $10 \%$.

The presence of chlorine in the analysed samples from the control field and the field fertilized with digestate remained fairly uniform (approximately $0.85 \%$ ), while rape straw collected from the field treated with NPK had a lower chlorine content $(0.69 \%)$. The addition of glycerol, due to its low content of chlorine, resulted in an approximate $10 \%$ reduction of the element's content in the pellets (Table 4 ). As reported by Król et al. [57], chlorine is most often present in biomass in the form of chloride ions $\mathrm{Cl}^{-}$, as well as small quantities of organochlorine compounds. Generally, the dry matter content of chlorine in biomass is under $2 \%$, although higher values tend to be reported for olive pomace, corn grain and straw. High chloride content in pellets may significantly contribute to a decrease of the melting point value, while at the same time exacerbating ash deposition on the heating elements of the furnace [62].

\section{Conclusions}

Concern for a clean natural environment forces scientist to work on the possibilities of using various waste materials of plant origin, which are also produced in the production of liquid and gaseous biofuels. Therefore, in our work, in the cultivation of spring rape, we decided to assess the impact of fertilization (using digestate and NPK) on the physical and chemical characteristics of straw and pellets made of it. At the same time, glycerol from FAME was used as an additive to mixtures with this straw during these tests. Based on this research, it was found that different methods of fertilization treatment applied during the cultivation of spring rape had a clear effect on the physicochemical properties of the obtained straw. In terms of the heating value of spring rape straw, the use of traditional NPK fertilization produced slightly less beneficial chemical parameters (lower carbon content and heat of combustion) when compared to the control sample and straw from the field fertilized with digestate. In all the analysed mixtures, the $10 \%$ addition of crude glycerol resulted in an improvement of the mechanical properties of the produced pellets. On the other hand, the energy use parameters of the fuel were slightly reduced.

The use of digestate and glycerol in the production of solid biofuels is having a great impact on the environment and society. In this way, we avoid treating such products as waste. This approach fits well with the concept of sustainable development. However, it would be useful to conduct research on the possibilities of using other waste raw materials for pellet production in terms of the impact on their physical and chemical characteristics.

Author Contributions: Conceptualization, M.K. (Magdalena Kachel) and A.K.; methodology, M.K. (Magdalena Kachel), A.K. and G.Z.; validation, A.S., A.P., S.P. and M.K. (Milan Koszel); formal analysis, M.K. (Magdalena Kachel), A.K. and G.Z.; investigation, A.K.; resources, A.P. and M.K. (Milan Koszel); data curation, M.K. (Magdalena Kachel); writing — original draft preparation, M.K. (Magdalena Kachel) and A.K.; writing—review and editing, A.K. and M.K. (Magdalena Kachel); visualization, M.K. (Magdalena Kachel); supervision, S.P.; project administration, M.K. (Magdalena Kachel) and A.K.; funding acquisition, A.S. and S.P. All authors have read and agreed to the published version of the manuscript.

Funding: This research was funded by the Polish Ministry of Science and Higher Education as part of the statutory work number TKR/DS/3/2018.

Conflicts of Interest: The authors declare no conflict of interest.

\section{References}

1. Żmija, D. Sustainable development of agriculture and rural areas in Poland. Economic policy at a time of transformation and crisis. Studia Ekon. Zesz. Nauk. Uniw. Ekon. W Katowicach 2014, 166, 149-158.

2. Chen, P.Y.; Chen, S.T.; Hsu, C.S.; Chen, C.C. Modeling the global relationships among economic growth, energy consumption and $\mathrm{CO}_{2}$ emissions. Renew. Sustain. Energy Rev. 2016, 65, 420-431. [CrossRef] 
3. Munir, S.; Daood, S.S.; Nimmo, W.; Cunliffe, A.M.; Gibbs, B.M. Thermal analysis and devolatilization kinetics of cotton stalk, sugar cane bagasse and shea meal under nitrogen and air atmospheres. Bioresour. Technol. 2009, 100, 1413-1418. [CrossRef] [PubMed]

4. García, R.; González-Vázquez, M.P.; Pevida, C.; Rubiera, F. Pelletization properties of raw and torrefied pine sawdust: Effect of co-pelletization, temperature, moisture content and glycerol addition. Fuel 2018, 215, 290-297. [CrossRef]

5. García, R.; Pizarro, C.; Lavín, A.G.; Bueno, J.L. Characterization of Spanish biomass wastes for energy use. Bioresour. Technol. 2012, 103, 249-258. [CrossRef]

6. García, R.; Pizarro, C.; Lavín, A.G.; Bueno, J.L. Biomass proximate analysis using thermogravimetry. Bioresour. Technol. 2013, 139, 1-4. [CrossRef]

7. Ściążko, M.; Zuwała, J.; Pronobis, M. Pros and cons of coincinerating biomass in power boilers in the context of the practical experience from the first year of coincinerating biomass on an industrial scale. Energetyka I Ekol. 2006, 2, 207-220.

8. Collins, S.; Wellner, N.; Martinez Bordonado, I.; Harper, A.; Miller, C.; Bancroft, I. Variation in the chemical composition of wheat straw: The role of tissue ratio and composition. Biotechnol. Biofuels 2014, 7, 1-14. [CrossRef]

9. Karcz, H.; Kantorek, M.; Grabowicz, M.; Wierzbicki, K. The feasibility of straw as a fuel source for power generating boilers. Inżynieria Środowiska. Piece Przemysłowe Kotty 2013, XI-XII, 8-15. (In Polish)

10. Arias, B.; Pevida, C.; Fermoso, J.; Plaza, M.G.; Rubiera, F.; Pis, J.J. Influence of torrefaction on the grindability and reactivity of woody biomass. Fuel Process. Technol. 2008, 89, 169-175. [CrossRef]

11. Kachel-Jakubowska, M.; Kraszkiewicz, A.; Szpryngiel, M.; Niedziółka, I. The possibilities of using waste products from winter rape for energy purposes. Agric. Eng. 2011, 6, 61-68.

12. Döring, S. Power from Pellets-Technology and Applications; Springer: Berlin/Heidelberg, Germany, 2013.

13. Matthews, F. Global Wood Pellet Market Outlook. In Proceedings of the WPAC Annual Conference, Halifax, UK, 3-5 November 2015.

14. Mola-Yudego, B.; Selkimäki, M.; González-Olabarria, J.R. Spatial analysis of the wood pellet production for energy in Europe. Renew. Energy 2014, 63, 76-83. [CrossRef]

15. Obernberger, I.; Brunner, T.; Bärnthaler, G. Chemical properties of solid biofuels—Significance and impact. Biomass Bioenergy 2006, 30, 973-982. [CrossRef]

16. Kachel-Jakubowska, M.; Kraszkiewicz, A.; Szpryngiel, M.; Niedziółka, I. Analysis of the characteristics of raw materials used in production of solid biofuels. Agric. Eng. 2013, 2, 103-111.

17. Kraszkiewicz, A.; Kachel-Jakubowska, M.; Niedziółka, I. The chemical composition of ash from the plant biomass in terms of indicators to assess slagging and pollution of surface heating equipment. Fresenius Environ. Bull. 2017, 26, 6383-6389.

18. Dhabhai, R.; Ahmadifeijani, E.; Dalai, A.K.; Reaney, M. Purification of crude glycerol using a sequential physico-chemical treatment, membrane filtration and activated charcoal adsorption. J. Sep. Purif. Technol. 2016, 168, 101-106. [CrossRef]

19. Manara, P.; Zabaniotou, A. Co-valorization of crude glycerol waste streams with conventional and/or renewable fuels for power generation and industrial symbiosis perspectives. Waste Biomass Valoriz. 2016, 7 , 135-150. [CrossRef]

20. Thompson, J.C.; He, B.B. Characterization of crude glycerol from biodiesel production from multiple feedstocks. Appl. Eng. Agric. 2006, 22, 261-265. [CrossRef]

21. Bartocci, P.; Bidini, G.; Asdrubali, F.; Beatrice, C.; Frusteri, F.; Fantozzi, F. Batch pyrolysis of pellet made of biomass and crude glycerol: Mass and energy balances. Renew. Energy 2018, 124, 172-179. [CrossRef]

22. Yang, F.; Hanna, M.; Sun, R. Value-added uses for crude glycerol-a by product of biodiesel production. Biotechnol. Biofuels 2012, 5, 1-10. [CrossRef]

23. Kalia, V.C.; Prakash, J.; Koul, S. Biorefinery for Glycerol Rich Biodiesel Industry Waste. Indian J. Microbiol. 2016, 56, 113-125. [CrossRef] [PubMed]

24. Zhang, X.; Yan, S.; Tyagi, R.D.; Surampalli, R.Y.; Valero, J.R. Energy balance of biofuel production from biological conversion of crude glycerol. J. Environ. Manag. 2016, 170, 169-176. [CrossRef] [PubMed]

25. EU-28. Global Agricultural Information Network-EU Biofuels Annual. 2016. Available online: http: //www.fas.usda.gov/data/eu-28-eu-biofuels-annua (accessed on 10 September 2019). 
26. Kijora, C.; Bergner, H.; Kupsch, R.D.; Hagemann, L. Glycerin also Futterkomponente in der Schweinmast. Arch. Tierernahr. 1995, 47, 345-360. [CrossRef] [PubMed]

27. Pronobis, M. Modernizacja Kotłów Energetycznych; Wydawnictwa Naukowo-Techniczne: Warszawa, Poland, 2002. (In Polish)

28. EN ISO 14110:2004. Fat and Oil Derivatives-Fatty Acid Methyl Esters (Fame)-Determination of Methanol Content; Polish Committee for Standardization: Warsaw, Poland, 2004.

29. MONG-Wt 93/2009. Internal Method-Technical Conditions for Determining MONG Content; Industry Standard, Trzebinia S.A. Refinery: Trzebinia, Poland, 2009.

30. Eur.Ph.2005:496. Chloride Content in Glycerine. In European Pharmacopoeia 5.0; Council of Europe: Strasbourg, France, 2005.

31. EN ISO 15104:2011. Solid Biofuels-Determination of Total Carbon, Hydrogen and Nitrogen Content-Instrumental Methods; Polish Committee for Standardization: Warsaw, Poland, 2011.

32. EN ISO 16948:2015-07. Solid Biofuels—Determination of Total Carbon, Hydrogen and Nitrogen Content; Polish Committee for Standardization: Warsaw, Poland, 2015.

33. EN ISO 14774-3:2010. Solid Biofuels—Determination of Moisture Content_Oven Dry Method_Part 3: Moisture in General Analysis Sample; Polish Committee for Standardization: Warsaw, Poland, 2010.

34. EN ISO 17828:2016. Solid Biofuels-Determination of Bulk Density; Polish Committee for Standardization: Warsaw, Poland, 2016.

35. EN ISO 17831-1:2015. Solid Biofuels. Determination of Mechanical Durability of Pellets and Briquettes. Pellets; Polish Committee for Standardization: Warsaw, Poland, 2015.

36. EN ISO 14775:2009. Solid Biofuels. Determination of Ash Content; Polish Committee for Standardization: Warsaw, Poland, 2009.

37. EN ISO 16994:2015-06. Solid Biofuels-Determination of Total Sulphur and Chlorine Content; Polish Committee for Standardization: Warsaw, Poland, 2015.

38. EN ISO 14918:2009. Solid Biofuels. Determination of Heating Value; Polish Committee for Standardization: Warsaw, Poland, 2009.

39. Kachel-Jakubowska, M.; Sujak, A.; Krajewska, M. Effect of Fertilizer and Storage Period on Oxidative Stability and Color of Rapeseed Oils. Pol. J. Environ. Stud. 2018, 27, 699-708. [CrossRef]

40. Koszel, M.; Kocira, A.; Lorencowicz, E. The evaluation of the use of biogas plant digestate as a fertilizer in alfalfa and spring wheat cultivation. Fresenius Environ. Bull. 2016, 25, 3258-3264.

41. Kathijotes, N.; Petrova, V.; Zlatareva, E.; Kolchakov, V.; Marinova, S.; Ivanov, P. Impacts of Biogas Digestate on Crop Production and the Environment: A Bulgarian Case Study. Am. J. Environ. Sci. 2015, 11, 81-89. [CrossRef]

42. Abubaker, J.; Risberg, K.; Pell, M. Biogas residues as fertilisers-effect on wheat growth and soil microbial activities. Appl. Energy 2012, 99, 126-134. [CrossRef]

43. Directive EC of the European parliament and of the council of 19 November 2008 on waste and repealing certain directives (Waste framework directive, R1 formula in footnote of attachment II). Off. J. Eur. Union L 2008, 312, 1-30.

44. Akhiar, A.; Battimelli, A.; Torrijos, M.; Carrere, H. Comprehensive characterization of the liquid fraction of digestates from full-scale anaerobic co-digestion. Waste Manag. 2017, 59, 118-128. [CrossRef]

45. Teglia, C.; Tremier, A.; Martel, J.L. Characterization of Solid Digestates: Part 2, Assessment of the Quality and Suitability for Composting of Six Digested Products. Waste Biomass Valoriz. 2011, 2, 113-126. [CrossRef]

46. Lima da Silva, A.; Mueller, I.L. Operation of solid oxide fuel cells on glycerol fuel: A thermodynamic analysis using the Gibbs free energy minimization approach. J. Power Sources 2010, 195, 5637-5644. [CrossRef]

47. Bohon, M.D.; Metzger, B.A.; Linak, W.P.; King, C.J.; Roberts, W.L. Glycerol combustion and emissions. Proc. Combust. Inst. 2011, 33, 2717-2724. [CrossRef]

48. Jagustyn, B.; Bątorek-Giesa, N.; Wilk, B. Evaluation of the properties of biomass used for energy purposes. Chemik 2011, 6, 557-559. (In Polish)

49. Topolnicka, T.; Zuwała, J.; Hrycko, P.; Muzyka, R. Crude glicerol as a bioliquid for renewable Energy generation in power sector. Przem. Chem. 2013, 92, 111-119.

50. Emami1, S.; Tabil, L.G.; Adapa, P. Effect of glycerol on densification of agricultural biomass. Int. J. Agric. Biol. Eng. 2015, 8, 64-74. 
51. Dyjakon, A.; Noszczyk, T. The Influence of Freezing Temperature Storage on the Mechanical Durability of Commercial Pellets from Biomass. Energies 2019, 12, 2627. [CrossRef]

52. EN ISO 14961-06:2012. Solid Biofuels-Fuel Specifications and Classes-Part 6: Non-Woody Pellets for Non-Industrial Use; Polish Committee for Standardization: Warsaw, Poland, 2012.

53. Demirbas, A. Combustion characteristics of different biomass fuels. Prog. Energy Combust. Sci. 2004, 30, 219-230. [CrossRef]

54. Kraszkiewicz, A.; Kachel-Jakubowska, M.; Niedziółka, I. Analysis of selected physical and chemical properties of plant biomass of agricultural origin in terms of its energy use. Bulg. J. Agric. Sci. 2015, 21, 1295-1299.

55. Nussbaumer, T. Combustion and co-combustion of biomass. In Proceedings of the 12th European Biomass Conference, Amsterdam, The Netherlands, 17-21 June 2002; Volume 1, pp. 31-37.

56. Kucinskas, V.; Jasinskas, A.; Butkus, V.; Jotautiene, E.; Pocius, A. Environmental assessment of sawdust blends with glycerol burning. In Proceedings of the 14th International Scientific Conference "Engineering for Rural Development", Jelgava, Latvia, 20-22 May 2015; pp. 336-341.

57. Król, D.; Łach, J.; Poskrobko, S. Selected problems related to the use of non-forest biomass in the power industry. Energetyka 2010, 1, 53-62. (In Polish)

58. Chen, W.S.; Lin, C.W.; Chang, F.C.; Lee, W.J.; Wu, J.L. Utilization of spent activated carbon to enhance the combustion efficiency of organic sludge derived fuel. Bioresour. Technol. 2011, 113, 73-77. [CrossRef]

59. Febrero, L.; Granada, E.; Patiño, D.; Eguía, P.; Regueiro, A. A comparative study of fouling and bottom ash from woody biomass combustion in a fixed-bed small-scale boiler and evaluation of the analytical techniques used. Sustainability 2015, 7, 5819-5837. [CrossRef]

60. Jin, X.; Ye, J.; Deng, L.; Che, D. Condensation behaviors of potassium during biomass combustion. Energy Fuels 2017, 31, 2951-2958. [CrossRef]

61. Munnings, C.; Kulkarni, A.; Giddey, S.; Badwal, S.P.S. Biomass to power conversion in a direct carbon fuel cell. Int. J. Hydrogen Energy 2014, 39, 12377-12385. [CrossRef]

62. Magdziarz, A.; Wilk, M.; Gajek, M.; Nowak-Woźny, D.; Kopia, A.; Kalemba-Rec, I.; Koziński, J.A. Properties of ash generated during sewage sludge combustion: A multifaceted analysis. Energy 2016, 113, 85-94. [CrossRef]

(C) 2020 by the authors. Licensee MDPI, Basel, Switzerland. This article is an open access article distributed under the terms and conditions of the Creative Commons Attribution (CC BY) license (http://creativecommons.org/licenses/by/4.0/). 